\title{
HFO1234yf as a Drop-in Replacement for R134a in Domestic Refrigerators: A Life Cycle Climate Performance Analysis
}

\author{
Ciro Aprea ${ }^{1}$, Adriana Greco ${ }^{2}$, Angelo Maiorino ${ }^{1}$, Claudia Masselli ${ }^{1 *}$ and Antonio Metallo ${ }^{1}$ \\ ${ }^{* 1}$ DIIN, University of Salerno, Via Giovanni Paolo II 132, 84084, Fisciano (SA), Italy \\ ${ }^{2}$ DII, University of Naples Federico II, P.le Tecchio 80, 80125, Napoli, Italy
}

Email: cmasselli@unisa.it

\begin{abstract}
Based on recent surveys, about $17 \%$ of the overall energy consumption comes out from refrigeration. Nowadays the use of environmentally friendly refrigerants has become a "must" in order to mitigate the global warming. A Vapor Compression Plant (VCP) produces typically both a direct and an indirect contribution to global warming where the first one is related to the Global Warming Potential (GWP) of the fraction of refrigerant charge, released accidentally in the atmosphere or not recovered when the system is scrapped. The employment of an environmental metric, in order to facilitate the choice of low GWP refrigerants, has to be implemented in VCPs. LCCP is one of the most comprehensive parameters which takes into account all the relevant indirect emissions related to the whole process of VCP and refrigerant manufacturing and their transportation. In this paper the results of an experimental comparative analysis between R134a and HFO1234yf, implemented in a domestic refrigerator, are presented. It have been measured energy consumptions under sub-tropical conditions in accordance with the UNI-EN-ISO15502. In addition a LCCP analysis, to evaluate the environmental impact due to HFO1234yf used as a substitute of $\mathrm{R} 134 \mathrm{a}$, is reported.
\end{abstract}

Keywords: Vapor compression system, Drop-in, R134a, HFO1234yf, LCCP.

\section{INTRODUCTION}

Roughly $17 \%$ of the worldwide energy consumption originates from refrigeration. Most modern refrigeration units are based on vapor compression plants (VCP). Since the beginning of their commercial diffusion, the development of the latter has been strictly related to the characteristics of working fluids. The traditional refrigerant fluids, i.e. CFCs and HCFCs, have been banned by the Montreal Protocol [1] because of their contribution to the disruption of the stratospheric ozone layer (Ozone-Depleting substances ODs) [2-4]; CFCs have been banned since 1996. In most of the European countries the use of the HCFCs has become forbidden in new systems since 2000, leaving HFCs as the only fluorinated refrigerants permitted in the EU whom do not contain chlorine and hence have zero Ozone Depletion Potential (ODP). Human activities have increased the concentration of greenhouse gases in the atmosphere. This resulted in a substantial warming of earth surface and atmosphere that adversely affected the natural ecosystem [5]. Thus, in addition to zero ODP, the working fluids in refrigeration systems must also have low global warming potential (GWP). Emissions of HCFs currently contribute about $1 \%$ of worldwide greenhouse gas emissions, but they are growing by $8-9 \%$ per year and are likely to further growth in the future [6]. The Kyoto Protocol [7], pursuant to the United Nations Framework Convention on Climate Change (UNFCCC), sets binding targets for greenhouse gas emissions. National laws and regulations implementing the Kyoto Protocol differ from one another, but they typically call for a phase down of HFC consumption. More recent measures, already adopted or proposed at local level (regional, national, municipal), are even more stringent. Based on the EU Regulation $\mathrm{N}^{\circ} 517 / 2014$ in domestic refrigerators and freezers, the use of HFCs, with 150 or more as GWP, has been banned from 1 January 2015. These restrictions are forcing the shift to a fourth generation of refrigerants with both ODP and GWP regulations [8].

One of the main field of energy consumption of refrigeration comes out from domestic refrigerators. R134a was the most widely used refrigerant in refrigerators for domestic application for its excellent thermodynamics and thermo-physical properties. Nevertheless, because of its 1430 as GWP, it will be phased-out soon, according to the Kyoto Protocol. Scientist and researchers are investigating [9-10] in development of environmentally friendly refrigerants for domestic refrigerators and freezers. Hydrocarbons $(\mathrm{HCs})$ especially propane, butane, isobutane and isobutane blends are proposed [11] as environmental benign refrigerants. They show many advantages like zero ODP, negligible GWP, low critical pressures and high enthalpy difference during evaporation process but, on the other side, the main 
disadvantages associated with their use lie in their high flammability and in not have a drop-in refrigerant nature because of its mismatching in volumetric cooling capacity and operating pressure. HCs are flammable and classified [12] in the range of low toxic, highly flammable refrigerants (A3). In spite of the high flammability these refrigerant fluids are used in new domestic refrigerators in Europe, but are forbidden in USA and Japan.

HFO refrigerants are actually unsaturated HFC refrigerants and widely recognized [13] as the next generation of refrigerants because of their environmental friendliness, costeffectiveness, and greater energy efficiencies. HFOs are distinguished from HFCs by being derivatives of olefins rather than alkanes (paraffins). Furthermore HFO are miscible in Polyolester (POE)-type lubricating oils; the miscibility of HFOs with POE lubricants is comparable to that of R134a.

A popular HFO refrigerant is HFO1234yf [14]. Table 1 reports a comparison between the thermodynamic, environmental and security properties of this refrigerant fluid and R134a. HFO1234yf has zero ODP and extremely low values of GWP which ensure that such refrigerant has a much shorter life cycle in the atmosphere than R134a. This HFO refrigerant has an $\mathrm{A} 2 \mathrm{~L}$ safety classification, meaning it has low toxicity but is slightly flammable. HFO1234yf has been developed as a replacement for HFC-134a in automobile air conditioning and it also can be considered as a drop-in of $\mathrm{R} 134 \mathrm{a}$ in existing vapor compression plants because of their similar thermodynamic behaviors. However, the main weaknesses of its employment could be found in its initial cost, higher than R134a.

Table 1. Properties of HFO1234yf in comparison with R134a

\begin{tabular}{llllc}
\hline Refrigerant & $\begin{array}{l}\text { Chemical } \\
\text { composition }\end{array}$ & $\begin{array}{l}\text { Mol. } \\
\text { weight } \\
{[\mathrm{g} . \mathrm{mol}-1]}\end{array}$ & $\begin{array}{l}\text { T crit. } \\
{\left[{ }^{\circ} \mathrm{C}\right]}\end{array}$ & $\begin{array}{l}\text { p critical } \\
{[\text { bar }]}\end{array}$ \\
\hline R134a & $\mathrm{CH}_{2} \mathrm{FCF}_{3}$ & 102 & 101.1 & 40.59 \\
\hline HFO1234yf & $\mathrm{CF}_{3} \mathrm{CF}_{2} \mathrm{CH}_{2}$ & 114 & 95.0 & 33.82 \\
\hline Refrigerant & $\begin{array}{l}\text { Normal } \\
\text { boiling point } \\
{\left[{ }^{\circ} \mathrm{C}\right]}\end{array}$ & $\begin{array}{l}\text { Safety } \\
\text { class }\end{array}$ & $\mathrm{ODP}$ & $\mathrm{GWP}$ \\
\hline R134a & -26.0 & $\mathrm{~A} 1$ & 0 & {$\left[\mathrm{~kg}_{\mathrm{CO} 2 . \mathrm{kg}-1]}\right.$} \\
\hline HFO1234yf & -29.0 & $\mathrm{~A} 2 \mathrm{~L}$ & 0 & 4 \\
\hline
\end{tabular}

A vapor compression plant produces typically both a direct and an indirect contribution to global warming where the first one is related to the GWP of the fraction of refrigerant charge released accidentally in the atmosphere or not recovered when the system is scrapped. The indirect contribution consists in the so-called energy-related contribution; it originates from $\mathrm{CO}_{2}$ emissions in the atmosphere due to the energy production processes. However, the employment of refrigerants with low direct impact doesn't carries consequentially to a low indirect impact in the VCP. Consequentially the employment of an environmental metric in order to facilitate the choice of low GWP refrigerants has to be implemented in VCPs. The Life Cycle Climate Performance LCCP is one of the most comprehensive parameters which takes into account all the relevant indirect emissions related to the whole process of VCP and refrigerant manufacturing and transportation.

In this paper is presented an experimental study of HFO1234yf as drop-in refrigerant in a wide range of working conditions in a fully monitored domestic refrigerator.
Furthermore, the results of an experimental comparative analysis between R134a and HFO1234yf are reported. It have been measured energy consumptions under sub-tropical conditions in accordance with the UNI-EN-ISO15502 [15].

\section{THE LCCP CONCEPT}

A number of methods for calculating the total incidence of global warming by a vapor compression plant, has been developed. The Total Equivalent Warming Impact (TEWI) index takes into account both contributions to global warming of the system. Through the TEWI concept, one can quantify the amount of $\mathrm{CO}_{2}$ released in the atmosphere due to system losses (direct impact) and energy consumption (indirect impact) related to the combustion of fossil fuels for the electric energy production.

The TEWI index is calculated as [16]:

$$
\begin{aligned}
& \mathrm{TEWI}=\mathrm{CO}_{2 \text { dir }}+\mathrm{CO}_{2 \text { indir }} \\
& \mathrm{CO}_{2, \text { dir }}=\mathrm{RC}\left[\mathrm{P}_{\mathrm{L}}+\left(\frac{1-\mathrm{REC}}{\mathrm{V}}\right)\right] \mathrm{V} \cdot \mathrm{GWP} \\
& \mathrm{CO}_{2 \text {,indir }}=\alpha \cdot \frac{\mathrm{Q}_{\mathrm{ref}}^{r}}{\mathrm{COP}} \cdot \mathrm{H} \cdot \mathrm{V}
\end{aligned}
$$

The direct global warming effect of refrigerant fluids, stemming from the absorption they produce of long-wave radiations, depends on their GWP and on the fraction of refrigerant charge released in the atmosphere. The last is mainly due to losses during the operational plant life time $\left(\mathrm{p}_{\mathrm{L}}\right)$ and to the residual amounts which, according to the current state of technology, are not recyclable and thus are released to the atmosphere when taking the plant out of operation (1REC). The main disadvantages of the TEWI approach is to not consider both the energy consumption and emissions, related to production and transportation of refrigerant or blowing agents.

The Life Cycle Climate Performance (LCCP) is a TEWI based methodology which provide a more accurate evaluation of the VCP impact on global warming, since it takes in account the energy consumption both for VCP operating both for the whole process of refrigerant productiontransportation-employment.

The LCCP index is calculated as [17]:

$$
\begin{aligned}
& \mathrm{LCCP}=\mathrm{CO}_{2, \text { dirt }}+\mathrm{CO}_{2, \text { indirt }} \\
& \mathrm{CO}_{2, \text { dirt }}=\operatorname{RC}\left\{\left[\mathrm{PL}_{\mathrm{L}}+\left(\frac{1-\mathrm{REC}}{\mathrm{V}}\right)+\mathrm{P}_{\mathrm{acc}}\right] \mathrm{V}+\mathrm{N}_{\text {serv }} \mathrm{P}_{\text {serv }}+\mathrm{P}_{\text {prod }}\right\} \mathrm{GWP} \\
& +\mathrm{RC}\left\{\left[\mathrm{PL}_{\mathrm{L}}+\left(\frac{1-\mathrm{REC}}{\mathrm{V}}\right)+\mathrm{Pacc}_{\mathrm{acc}}\right] \mathrm{V}+\mathrm{N}_{\text {serv }} \mathrm{P}_{\text {serv }}+\mathrm{P}_{\text {prod }}\right\} \mathrm{GWP} \text { adp }
\end{aligned}
$$

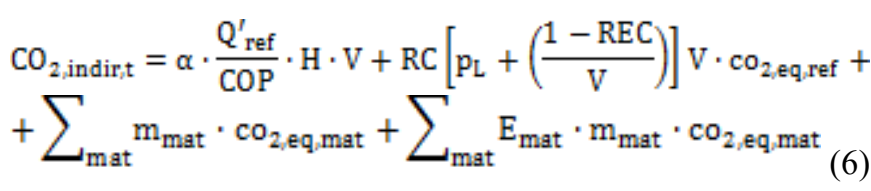

The direct contribution includes the one above mentioned in (2) with, in addition, the refrigerant leakages due to: accidents, system servicing operation and refrigerant 
production and transport. The last term of the direct contribution takes into account the reaction byproduct of the atmospheric breakdown of the refrigerant emissions by means

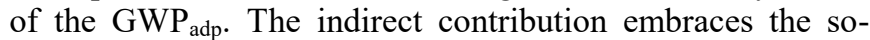
called energy-related contribution which originates from $\mathrm{CO}_{2}$ emissions in the atmosphere due to the energy consumption of the system, the energy required for refrigerant producing, system and components manufacturing and the energy contribution for end-of-life recycling/recovery of system and refrigerant.

In the evaluation of LCCP index for both refrigerants considered in this paper all the leak rates and the $\mathrm{CO}_{2}$ emissions per material kilo, related to the indirect contribution, come from 16.05.2015 data proper of International Institute of Refrigeration (IIR). The $\mathrm{CO}_{2}$ emission rate per $\mathrm{kWh}$ has been estimated by Ecometrica 2011 [18], whereas through the RAEE standard [19], based on $81 \mathrm{~kg}$ as the refrigerator net mass, it has been estimated the amount of all materials composing the tested VCP. Both the GWP (Table 1) and the $\mathrm{GWP}_{\mathrm{adp}} \quad\left(\mathrm{GWP}_{\mathrm{adp}}, \mathrm{CO}_{2}=0\right.$; $\mathrm{GWP}_{\mathrm{adp}}, \mathrm{HFO}=3.3$ ) index values are provided by the Europ. Dir. 517/2014 [20].

\section{EXPERIMENTAL APPARATUS}

Experimental tests are carried out through an experimental apparatus composed by a vapor compression plant, an investigation apparatus and a virtual instrument for performances and criticality analysis. A block diagram of the VCP is represented in Figure 1.

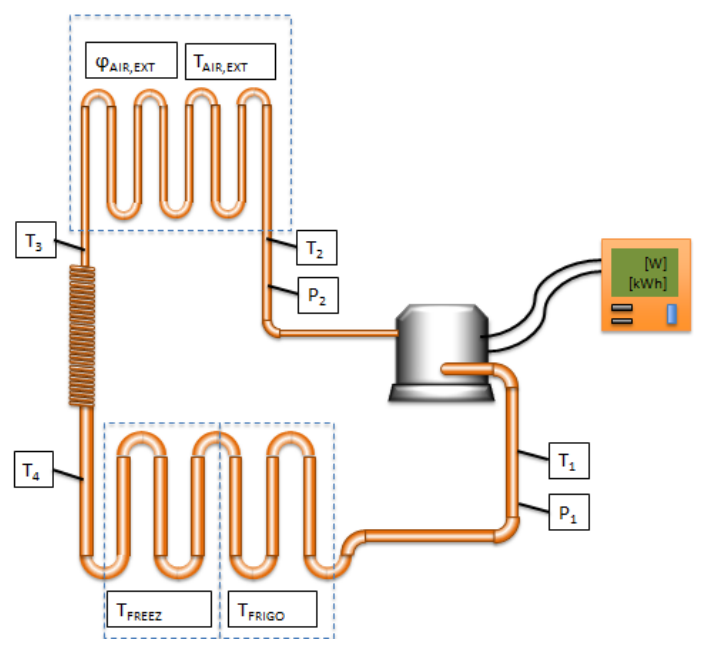

Figure 1. Block diagram of the VCP

The refrigerant system considered for experimental test is a double port Samsung domestic refrigerator. EU Directive 92/75/EC [18] established an energy consumption EU Energy Label scheme for refrigerators. The energy efficiency of the appliance is rated in terms of a set of energy efficiency classes initially from $A$ to $G$ on the label, A being the most energy efficient, $G$ the least efficient. In an attempt to keep up with advances in energy efficiency, since 2010, A+, A++ and $\mathrm{A}+++$ grades were introduced. The refrigerator under test above mentioned, belongs to the A+ class for energy efficiency.
The experimental investigation consisted in: measurement of temperature, through the placement of 9 PT100 thermoresistances (accuracy $\pm 0.1 \mathrm{~K}$ ) in the circuit; indirect evaluation of high and low VCP pressures, considering the difficult in direct pressure detecting into the heat exchanger serpentines. In particular, through the REFPROP calculation software, pressure values have been easily obtained by temperature detections at the saturation curve of the refrigerant utilized into the refrigerator. To evaluate the environmental relative humidity the Protimeter System 996 Precision Humidity Measurement System has been placed in the room test. A network analyzer, named Energy Test, has also been considered for the evaluation of energy and power consumptions for both the tested refrigerants. For real time monitoring of pressure and temperature evolutions into the whole vapor compression cycle under test, a virtual instrument in Labview area, named Frigocheck 2.0, has been developed.

\section{EXPERIMENTAL TESTS ANS RESULTS}

In this work, energy performances of R134a are compared with HFO1234yf. Furthermore an LCCP analysis for both fluids under test have been conducted.

All the experimental tests have been conducted according to the UNI-EN-ISO15502. The standard requires 24-hour tests while the refrigerator is in an environment which presents $25^{\circ} \mathrm{C}$ as average temperature and a relative humidity confined in the $45 \div 75 \%$ range. To operate in accordance with the above standard, it is also necessary that during the 24hour tests, the refrigerator experiences at least one defrost cycle. The experimental tests have been performed while the refrigerator was working at an average values of $5^{\circ} \mathrm{C}$ for $\mathrm{T}_{\mathrm{FRIGO}}$ with a charge of $101 \mathrm{~g}$ for R134a experiments and of $115 \mathrm{~g}$ for HFO1234yf. The last value is the optimal charge.

All the tests have been evaluated while $\mathrm{T}_{\text {FREEZ }}$ and was set at average values of $\alpha^{\circ} \mathrm{C}$ and $-26^{\circ} \mathrm{C}$.

In the Figures 2-3 are shown the temperature trends at the evaporator during an operation time of $24 \mathrm{~h}$ (1440 minutes) for both fluids. From the figures one can observe that the two fluids exhibits the same behaviors, but R1234yf shows always lower values of the evaporating temperature.

Figures 4-5 exhibits evolution of the temperature at inlet of compressor during an operation time of $24 \mathrm{~h}$ for both fluids. Tests with HFO1234yf register a small decrease of such temperature, with respect to $\mathrm{R} 134 \mathrm{a}$, due the greater charge of the former refrigerant $(115 \mathrm{~g})$ than the latter $(101 \mathrm{~g})$.

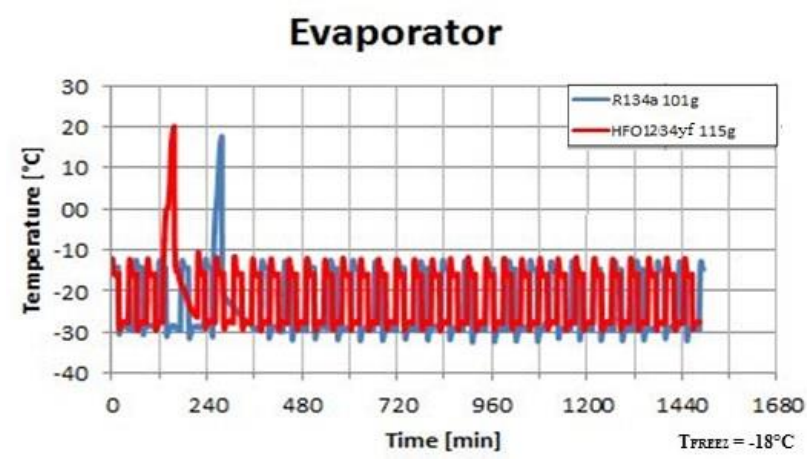

Figure 2. Temperature at the evaporator during 24-hour test for R134a and HFO1234yf, with $\mathrm{T}_{\mathrm{FREEZ}}=-18^{\circ} \mathrm{C}$ 


\section{Evaporator}

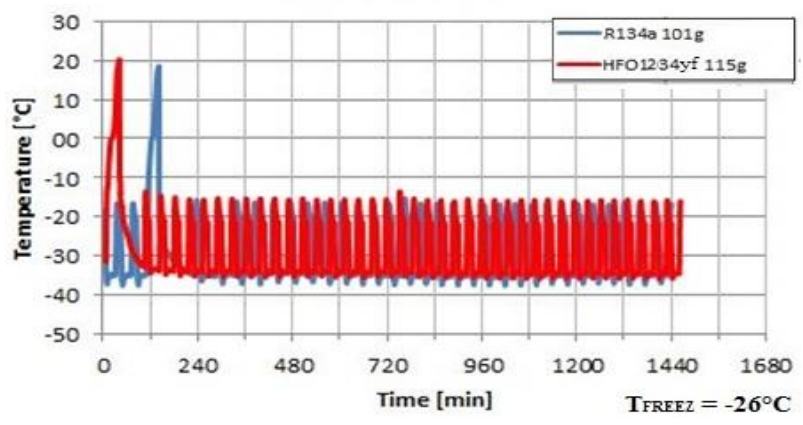

Figure 3. Temperature at the evaporator during 24-hour test for R134a and HFO1234yf, with $\mathrm{T}_{\mathrm{FREEZ}}=-26^{\circ} \mathrm{C}$

\section{Inlet of compressor}

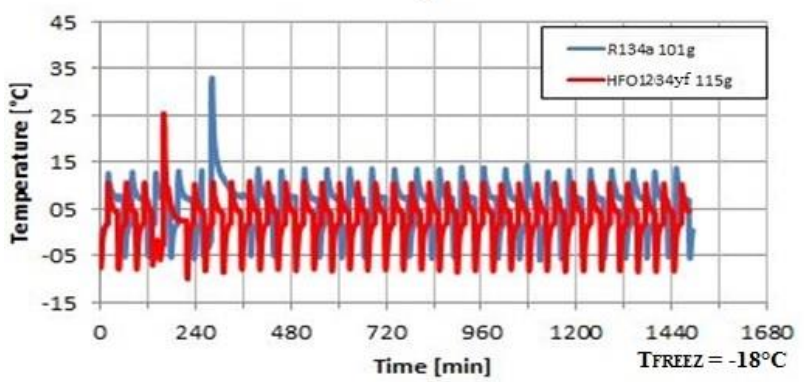

Figure 4. Temperature at inlet of compressor during 24-hour test for R134a and HFO1234yf, with $\mathrm{T}_{\mathrm{FREEZ}}=-18^{\circ} \mathrm{C}$

\section{Inlet of compressor}

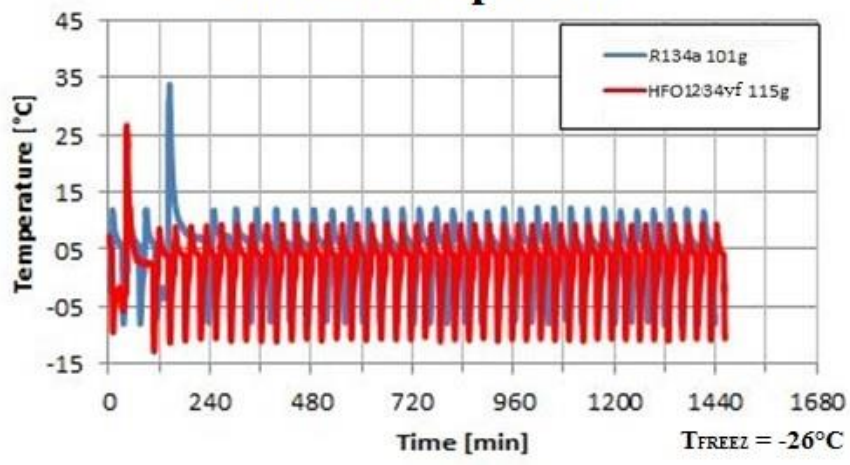

Figure 5. Temperature at inlet of compressor during 24-hour test for R134a and HFO1234yf, with $\mathrm{T}_{\mathrm{FREEZ}}=-26^{\circ} \mathrm{C}$

In Figure 6 are reported the air temperatures of the cold and the freezer cells, where one can observe that both the fluids have a good response at the $\mathrm{T}_{\text {FREEZ }}=-18^{\circ} \mathrm{C}$ setting; whereas in the cold cell, HFO1234yf swings around $\mathrm{T}_{\mathrm{FRIGO}}=$ $4^{\circ} \mathrm{C}$, rather than the required value of $5^{\circ} \mathrm{C}$.

Figure 7 reports air temperature in cold and freezer cells when the refrigerator setting is: $\mathrm{T}_{\mathrm{FRIGO}}=5^{\circ} \mathrm{C}, \mathrm{T}_{\mathrm{FREEZ}}=-26^{\circ} \mathrm{C}$. It is clearly appreciable that, although in the freezer cell both R134a and HFO1234yf swing with the same trend around a $\mathrm{T}_{\mathrm{FREEZ}}$ close to $-26^{\circ} \mathrm{C}$, in the cold cell none of the two refrigerants meets the demand of maintaining $\mathrm{T}_{\mathrm{FRIGO}}$ at $5^{\circ} \mathrm{C}$, so the cell is colder than expected. Such anomalous behaviors of the air temperature into the cold cell of the refrigerator has to be attributed to damper effect. The damper is an independent thermostat which opens or closes the air conveyor, that allows an air blowing from the freezer to the cold cell, to adjust the temperature of the latter. Since that in the refrigerator under test the evaporator is located only into the freezer cell, the cold cell cooling is done by air vents. Therefore, when the refrigerator is working at $\mathrm{T}_{\mathrm{FREEZ}}=-26^{\circ} \mathrm{C}$, the air flux from freezer to cold cell cools more than needed and $\mathrm{T}_{\mathrm{FRIGO}}$ falls below $5^{\circ} \mathrm{C}$ when the damper effect takes place.

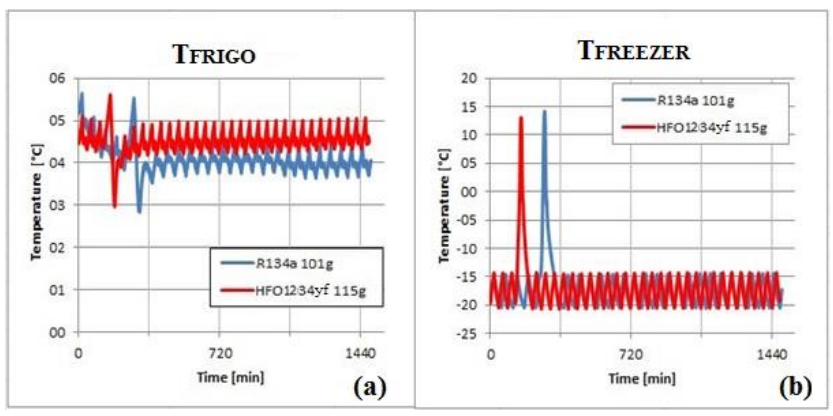

Figure 6. (a) Air temperature of the cold cell set at $5^{\circ} \mathrm{C}$; (b) temperature of the freezer cell set at $-18^{\circ} \mathrm{C}$

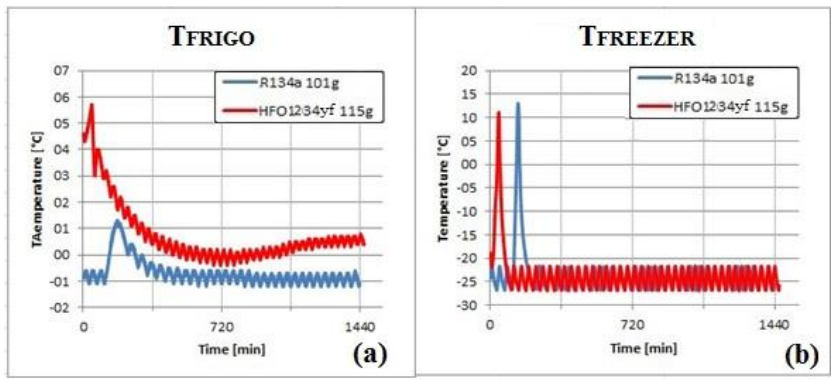

Figure 7. (a) Air temperature of the cold cell in 24 hours; (b) temperature of the freezer cell averaged at $-26^{\circ} \mathrm{C}$

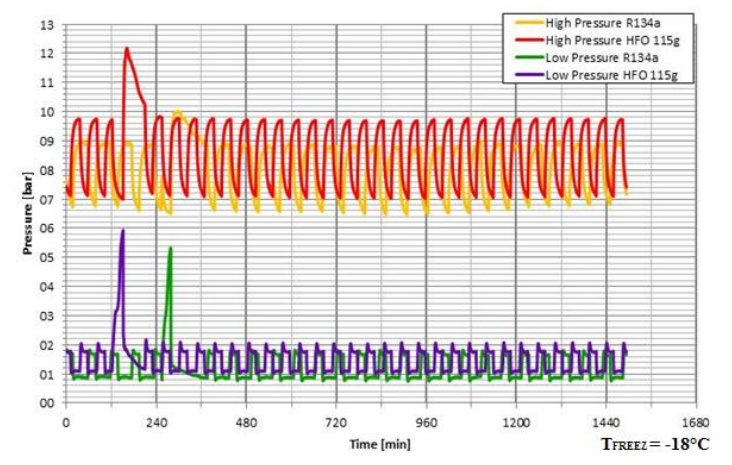

Figure 8. High and low pressures during 24-hour test for $\mathrm{R} 134 \mathrm{a}$ and HFO1234yf, with $\mathrm{T}_{\mathrm{FREEZ}}=-18^{\circ} \mathrm{C}$

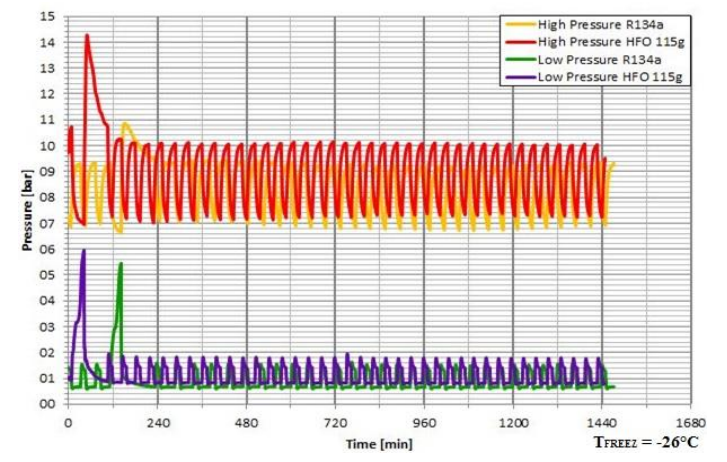

Figure 9. High and low pressures during 24-hour test for $\mathrm{R} 134 \mathrm{a}$ and HFO1234yf, with $\mathrm{T}_{\mathrm{FREEZ}}=-26^{\circ} \mathrm{C}$ 
In the Figures 8 and 9 are plotted the high and low pressure trends of the tested vapor compression cycle for the refrigerator working with R134a and with HFO1234yf while $\mathrm{T}_{\text {FREEZ }}$ is set at $-18^{\circ} \mathrm{C}$ and $-26^{\circ} \mathrm{C}$, respectively. One can observe that the high HFO1234yf pressure is approximately $10 \%$ greater than $\mathrm{R} 134 \mathrm{a}$, whereas the low ones are quite the same for both the $\mathrm{T}_{\text {FREEZ }}$ settings. Moreover HFO1324yf presents a roughly $20 \%$ larger peaks of high pressure, in correspondence of defrost cycle either in $-18^{\circ} \mathrm{C}$ than in $-26^{\circ} \mathrm{C}$ tests. Indeed, with HFO1234yf, the whole circuit is subject to greater pressure, resulting in increases of losses and mechanical stress for compressor.

Figures 10 and 11 show the refrigerator's average refrigerant power during an operation time of $24 \mathrm{~h}$ for both the tested fluids and the freezer cell temperature settings. From the figures ON-OFF cycles of the compressor are regular and clearly visible, whereas the highest peaks are characteristics of the defrost cycle.

Average power of the refrigerator working with HFO1234yf are $17 \%$ greater than with R134a for both $-18^{\circ} \mathrm{C}$ and $-26^{\circ} \mathrm{C}$. Such behavior is due to the similar values of temperature at the evaporator, shown by the two tested fluids, but with a greater subcooling for HFO1234yf that leads to a greater value of the latent heat of evaporation.

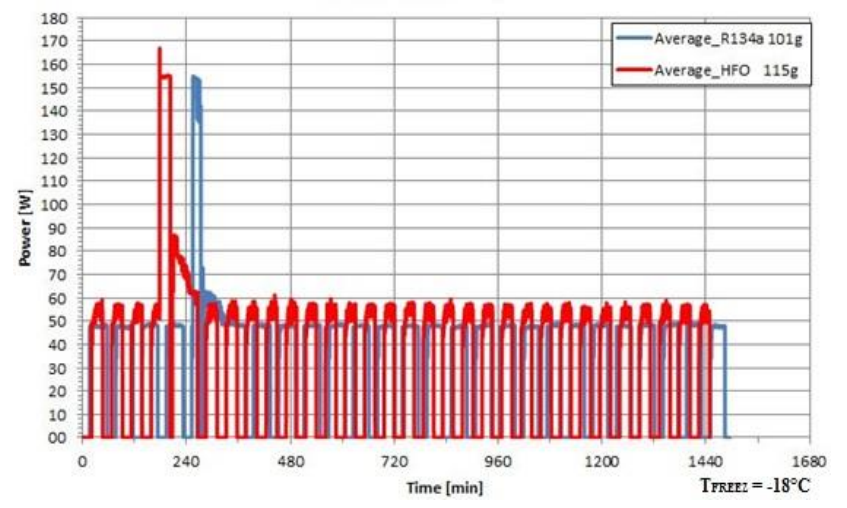

Figure 10. 24-hours average power for R134a and HFO1234yf, with $\mathrm{T}_{\mathrm{FREEZ}}=-18^{\circ} \mathrm{C}$

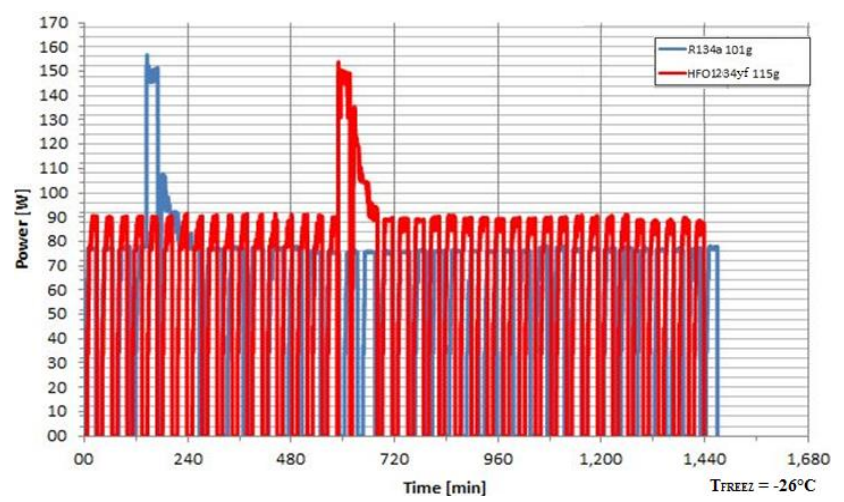

Figure 11. 24-hours average power for R134a and HFO1234yf, with $\mathrm{T}_{\mathrm{FREEZ}}=-26^{\circ} \mathrm{C}$

In order to evaluate the performances of the regenerator in both cases, the COP has been evaluated as:

$\mathrm{COP}=\frac{\mathrm{Q}_{\mathrm{ref}}}{W}$
Supposing to work with the same mass flow rate for 24hour and therefore the same density, is possible to consider that for both fluid $\mathrm{Q}_{\text {ref }}$ is the same, since that the test are done at equal thermal load, supposing the same defrosting period length.

It is also useful to introduce a performance index calculated as:

$\varepsilon=\frac{\operatorname{COP}_{\text {HFO }}}{\operatorname{COP}_{\text {R114a }}}=\frac{\frac{1}{\hat{W}_{\text {HFO }}}}{\frac{1}{\hat{W}_{\text {R134a }}}}$

Table 2 exhibits daily and annual energy consumptions for the tests performed, the index of performance and the percentage of energy saving in working with HFO1234yf, rather than $\mathrm{R} 134 \mathrm{a}$. When $\mathrm{T}_{\text {FREEZ }}$ is set to $-18^{\circ} \mathrm{C}$, a power reduction of around $2.60 \%$ is registered if the refrigerator is working with $115 \mathrm{~g}$ of HFO1234yf, rather than $101 \mathrm{~g}$ of R134a. On the other side if $\mathrm{T}_{\mathrm{FREEZ}}=-26^{\circ} \mathrm{C}$, cooling with HFO1234yf would provide the power consumption is $0.4 \%$ greater than R134a. The higher energy consumption, for HFO1234yf tests, detected when $\mathrm{T}_{\mathrm{FREEZ}}=-26^{\circ} \mathrm{C}$, could be probably attributed to the higher condensing pressures which could be symptom of a worst convective heat exchange at the condenser.

Table 2. Power consumption and energy saving for the test performed

\begin{tabular}{llllll}
\hline Test & $\begin{array}{l}24-\mathrm{h} \\
\text { cons. } \\
{[\mathrm{Wh}]}\end{array}$ & $\begin{array}{l}\text { Annual } \\
\text { cons. } \\
{[\mathrm{kWh}]}\end{array}$ & $\begin{array}{l}\text { Average } \\
\text { Power } \\
\text { On } \\
{[\mathrm{W}]}\end{array}$ & $\begin{array}{l}\varepsilon \\
{[-]}\end{array}$ & $\begin{array}{l}\text { En. } \\
\text { Sav. } \\
{[\%]}\end{array}$ \\
\hline $\begin{array}{l}\text { R134a } \\
\text { TFREEZ }=-18^{\circ} \mathrm{C}\end{array}$ & 792.8 & 289.4 & 47.4 & 1.000 & 0 \\
\hline $\begin{array}{l}\text { HFO1234yf } \\
\text { TFREEZ }=-18^{\circ} \mathrm{C}\end{array}$ & 772.5 & 281.9 & 52.4 & 1.026 & +2.6 \\
\hline $\begin{array}{l}\text { R134a } \\
\text { TFREEZ=-26 }{ }^{\circ} \mathrm{C}\end{array}$ & 1294.5 & 472.5 & 70.5 & 1.000 & 0 \\
\hline $\begin{array}{l}\text { HFO1234yf } \\
\text { TFREEZ }=-26^{\circ} \mathrm{C}\end{array}$ & 1299.9 & 474.5 & 80.9 & 0.996 & -0.4 \\
\hline
\end{tabular}

In the evaluation of LCCP direct contribution $101 \mathrm{~g}$ of $\mathrm{R} 134 \mathrm{a}$ and $115 \mathrm{~g}$ of HFO1234yf as refrigerant masses, together with their GWP indexes, have been considered.

Table 3. Reference values for calculating LCCP direct contribution

\begin{tabular}{lll}
\hline Parameter & R134a & HFO1234yf \\
\hline $\mathrm{m}[\mathrm{kg}]$ & 0.101 & 0.115 \\
\hline GWP [kgCO2.kg-1] & 1430 & 4 \\
\hline GWP $_{\text {adp }}[\mathrm{kg}$ CO2.kg-1] & 1.6 & 3.3 \\
\hline $\mathrm{p}_{\mathrm{L}}[\% . \mathrm{yr}-1]$ & 2.5 & 2.5 \\
\hline $\mathrm{p}_{\text {acc }}[\% . \mathrm{yr}-1]$ & 10 & 10 \\
\hline $\mathrm{REC}[\%]$ & 85 & 85 \\
\hline $\mathrm{V}$ [yr] & 15 & 15 \\
\hline $\mathrm{N}_{\text {serv }}[-]$ & 1 & 1 \\
\hline $\mathrm{P}_{\text {serv }}[\%]$ & 5 & 5 \\
\hline $\mathrm{P}_{\text {prod }}[\%]$ & 0 & 0 \\
\hline
\end{tabular}


In Table 3 are reported the reference values for the evaluation of the direct contribution of both fluids according to equation (5).

On the other side, to estimate the indirect contribution, all the leak rates and the $\mathrm{CO}_{2}$ emissions per material kilo and per $\mathrm{kWh}$ come from scientific literature data. In particular it has been considered $\alpha=0.435 \mathrm{~kg}_{\mathrm{CO} 2} \cdot \mathrm{kWhyr}-1$. By means of the RAEE standard [19], based on $81 \mathrm{~kg}$ as the refrigerator net mass, it has been estimated the amount of all materials from which it is made. Table 4 reports all the materials composing the refrigerator.

Table 4. Materials composing the refrigerator

\begin{tabular}{llll}
\hline Material & $\mathrm{CO}_{2, \text { eq mat }}$ & $\begin{array}{l}\text { Mass of } \\
\text { material } \\
{[\mathrm{kg}]}\end{array}$ & $\begin{array}{l}\text { Mass of } \\
\text { material /total } \\
\text { mass } \\
{[\%]}\end{array}$ \\
\hline Aluminium & 12.60 & 5.2 & 6.5 \\
\hline Copper & 3.00 & 2.2 & 2.7 \\
\hline Plastic & 2.80 & 8.1 & 10.0 \\
\hline $\begin{array}{l}\text { Polyuretha } \\
\text { ne }\end{array}$ & 4.02 & 12.5 & 15.4 \\
\hline Steel & 1.80 & & \\
\hline
\end{tabular}

Table 5 provides the LCCP index values, together with the single $\mathrm{CO}_{2}$ direct and indirect contributions, for both refrigerants and with references to the 24-hours tests with $\mathrm{T}_{\text {FREEZ }}$ values of: $-18^{\circ} \mathrm{C}$ and $-26^{\circ} \mathrm{C}$.

Table 5. The LCCP indexes

\begin{tabular}{llll}
\hline Test & $\begin{array}{l}\mathrm{LCCP} \\
{\left[\mathrm{kg}_{\mathrm{CO} 2}\right]}\end{array}$ & $\begin{array}{l}\mathrm{CO}_{2, \text { dir,t }} \\
{\left[\mathrm{kg}_{\mathrm{CO} 2}\right]}\end{array}$ & $\begin{array}{c}\mathrm{CO}_{2, \text { indir,t }} \\
{\left[\mathrm{kg}_{\mathrm{CO} 2}\right]}\end{array}$ \\
\hline $\begin{array}{l}\mathrm{R} 134 \mathrm{a} \\
\mathrm{T}_{\text {FREEZ }=-18}{ }^{\circ} \mathrm{C}\end{array}$ & 2407.2 & 306.0 & 2101.2 \\
\hline $\begin{array}{l}\mathrm{HFO} 1234 \mathrm{yf} \\
\mathrm{T}_{\text {FREEZ }=-18} \mathrm{C}\end{array}$ & 2069.1 & 15.9 & 2053.3 \\
\hline $\mathrm{R} 134 \mathrm{a}$ & 3603.3 & 306.0 & 3297.3 \\
$\mathrm{~T}_{\text {FREEZ }}=-26^{\circ} \mathrm{C}$ & & & \\
\hline $\begin{array}{l}\mathrm{HFO} 1234 \mathrm{yf} \\
\mathrm{T}_{\text {FREEZ }=-26} \mathrm{C}\end{array}$ & 3326.3 & 15.9 & 3310.5 \\
\hline
\end{tabular}

For both TFREEZ considered, the relative calculated LCCP for HFO1234yf is always lower than R134a. In particular, thanks to the drop-in of HFO1234yf in place of $\mathrm{R} 134 \mathrm{a}$, a reduction in $\mathrm{CO}_{2}$ emissions of $14 \%$ (test with $\mathrm{T}_{\mathrm{FREEZ}}$ $=-18^{\circ} \mathrm{C}$ ) and $7 \%$ (test with $\mathrm{T}_{\mathrm{FREEZ}}=-26^{\circ} \mathrm{C}$ ) is registered. This is mainly due to the total direct contribution on global warming of HFO1234 since that it is about 20 times lower than R134a. Furthermore, at the same $\mathrm{T}_{\text {FREEZ }}$ one can observe that total indirect contribution on global warming, for R134a and HFO1234yf, are approximately the same.

\section{CONCLUSIONS}

In this paper the results of an experimental comparative analysis between R134a and HFO1234yf, implemented in a domestic refrigerator, are presented. It have been measured energy consumptions under sub-tropical conditions in accordance with the UNI-EN-ISO15502. In addition, a LCCP analysis, to evaluate the environmental impact from a global point of view, due to HFO1234yf used as a substitute of
$\mathrm{R} 134 \mathrm{a}$, is reported. $\mathrm{R} 134 \mathrm{a}$ has a relevant direct global warming effect stemming from its absorption power of longwave radiations, which depends on its GWP and on the fraction of refrigerant charge released in the atmosphere. A possible substitute of R134a can be HFO1234yf, unsaturated HFO refrigerant with a very low global warming potential.

By means of experimental tests conducted on an A+ class domestic refrigerator working first with R134a and then with HFO1234yf, we can conclude that the latter is a valid substitute of R134a. Indeed, HFO1234yf total direct impact on global warming is very low, since it presents a very small GWP with respect to R134a, more than one thousand higher. Regards to the indirect impact, for R134a and HFO1234yf, is approximately the same.

Therefore the relative calculated LCCP for HFO1234yf is always lower than R134a.

\section{REFERENCES}

[1] Montreal Protocol on substances that deplete the ozone layer, United Nation Environment Program (UN), New York, NY, USA, 1987.

[2] Greco, A., Mastrullo, R. and Palombo, A., "R407C as an alternative to R22 in vapour compression plant: An experimental study," Int. J. En. Res., vol. 21, pp. 10871098, 1997. DOI: $10.1002 /($ SICI)1099$114 \mathrm{X}(19971010) 21: 12<1087::$ AID-ER330>3.0.CO;2Y.

[3] Aprea, C. and Greco, A, "An experimental evaluation of the greenhouse effect in R22 substitution." En. Conv. Man., vol. 39, pp. 877-887, 1998. DOI: 10.1016/S0196-8904(97)10058-9.

[4] Greco, A. and Vanoli, G.P., "Experimental two-phase pressure gradients during evaporation of pure and mixed refrigerants in a smooth horizontal tube. Comparison with correlations." Heat and Mass Transfer/Waerme- und Stoffuebertragung, vol. 42 pp. 709-725, 2006. DOI: $10.1007 / \mathrm{s} 00231-005-0020-7$.

[5] Mirandola, A. and Lorenzini E., "Energy, Environment and Climate: From the Past to the Future." Int. J. of Heat and Technology, vol. 34 (2) pp. 159-164, 2016. DOI: $10.18280 /$ ijht.340201.

[6] Delmastro, C., Mutani, G., Schranz, L. and Vicentini, G., "The Role of Urban Form and Socio-Economic Variables for Extimating the Building Energy Savings Potential at the Urban Scale", Int. J. of Heat and Technology, vol. 33, no. 4, pp. 91-100, 2015 DOI: 10.18280/ijht.330412.

[7] Kyoto Protocol to the United nation Framework Convention on climate change, Kyoto, JPN, 1997.

[8] Calm, J. M., "The next generation of refrigerant historical review," Int. J. Refr., vol. 31, no. 7, pp. 1123-1133, 2008.2 DOI: 10.1016/j.ijrefrig.2008.01.013.

[9] Aprea, C., Greco, A. and Maiorino, A., "An experimental evaluation of the greenhouse effect in the substitution of R134a with $\mathrm{CO}_{2}$." Energy, vol. 45, pp. 753-761, 2012. DOI: 10.1016/j.energy.2012.07.015.

[10] Aprea C., Greco A. and Maiorino A., "The substitution of R134a with R744: an exergetic analysis based on experimental data." Int. J. Refr., vol. 36 pp. 21482159, 2013. DOI: 10.1016/j.ijrefrig.2013.06.012.

[11] M. A. Sattar, R. Saidur and H. H. Masjuki, "Performance investigation of domestic refrigerator 
using pure hydrocarbons and blends of hydrocarbons as refrigerant," Proc of WASET, 2007, vol. 23, pp. 223-228.

[12] Designation and Safety Classification of Refrigerant, ANSI/ASHRAE standard 34, 2001.

[13] Mota-Babiloni, A., Navarro-Esbrí, J., Barragán, Á., Molés, F. and Peris, B., "Drop-in energy performance evaluation of R1234yf and R1234ze (E) in a vapor compression system as R134a replacements," Appl. Therm. Eng., vol. 71, no. 1, pp. 259-265, 2014. DOI: 10.1016/j.applthermaleng.2014.06.056.

[14] Aprea, C., Greco, A. and Maiorino, A, "An experimental investigation on the substitution of HFC134a with HFO1234yf in a domestic refrigerator." Appl. Therm. Eng., vol. 106 pp. 959-967, 2016. DOI: 10.1016/j.applthermaleng.2016.06.098.

[15] Household refrigerating appliances - Characteristics and test methods, UNI-EN-ISO 15502, 2005.

[16] Aprea, C., Greco, A., Maiorino, A. and Masselli, C., "Magnetic refrigeration: an eco-friendly technology for the refrigeration at room temperature," $J$. of Phys.: Conf. Ser., vol. 655, no. 1, pp 1-13, 2015. DOI: $\underline{10.1088 / 1742-6596 / 655 / 1 / 012026 .}$.

[17] Beshr, M., Aute, V., Sharma, V., Abdelaziz, O., Fricke, B. and Radermacher, R., "A comparative study on the environmental impact of supermarket refrigeration systems using low GWP refrigerants", Int. J. Refr., vol. 56, pp. 154-164, 2015. DOI: 10.1016/i.ijrefrig.2015.03.025.

[18] M. Brander, A. Sood, C. Wylie, A. Haughton and J. Lovell, "Electricity-specific emission factors for grid electricity," Ecometrica, Edinburg, UK, 2011.

[19] RAEE, Rapporto annuale sul sistema di ritiro e trattamento dei rifiuti da apparecchiature elettriche ed elettroniche in Italia, 2010, Italy.

[20] EU No 517/2014, European Regulation No 517/2014 on fluorinated greenhouse gases and repealing Regulation (EC) No 842/2006, Off. J. Eur. Union, 2014.

\section{NOMENCLATURE}

$\mathrm{CO}_{2}$
$\mathrm{CO}_{2}$

COP

$\mathrm{E}$

GWP

LCCP

$\mathrm{H}$

m

$\mathrm{N}$

$\mathrm{p}$

$\mathrm{P}$

Q'

$\mathrm{RC}$

REC

$\mathrm{T}$

TEWI

$\mathrm{V}$

W

\section{Greek symbols}

$\alpha$

$\varepsilon$

\section{Subscripts}

acc

adp

dir

eq

FREEZ

FRIGO

HFO

indir

L

mat

prod

$\mathrm{R}$

ref

serv

$\mathrm{t}$
$\mathrm{CO}_{2}$ contribution to global warming, $\mathrm{kg}_{\mathrm{CO} 2}$

coefficient of performance

percent of energy for recycling, $\%$

global warming potential, $\mathrm{kg}_{\mathrm{CO} 2} \cdot \mathrm{kg}-1$

life cycle climate performance, $\mathrm{kg}_{\mathrm{CO} 2}$

annual operating hours, h.yr-1

mass, $\mathrm{kg}$

dimensionless total number

percent annual refrigerant leak rate, $\%$.yr-1

percent leak rate, $\%$

power, $\mathrm{kW}$

refrigerant charge, $\mathrm{kg}_{\mathrm{CO} 2}$

refrigerant recycling rate, $\%$

temperature, ${ }^{\circ} \mathrm{C}$

total equivalent warming impact, $\mathrm{kg}_{\mathrm{CO} 2}$

plant useful life, yr

electricity demand, $\mathrm{kW}$

$\mathrm{CO}_{2}$ emission from power conversion, $\mathrm{kg}_{\mathrm{CO} 2} \cdot \mathrm{kWhyr}-1$

dimensionless performance index

accidental

atmospheric degradation product of the refrigerant

direct

equivalent

freezer cell

cold cell

HFO1234yf

indirect

regular

material

refrigerant production and transport

refrigerant recycling

refrigerant

system servicing

total 